\title{
THE INFLUENCE OF PLASTICISING ADMIXTURES ON DRYING SHRINKAGE OF CEMENTITIOUS COMPOSITES
}

\author{
Gintautas SKRIPKIŪNAS ${ }^{1}$, Mindaugas MACIJAUSKAS ${ }^{1^{*}}$, \\ Grigory YAKOVLEV ${ }^{2}$, Anastasiia IGNATYEVA ${ }^{2}$ \\ ${ }^{1}$ Department of Building Materials and Fire Safety, Vilnius Gediminas Technical University, \\ Sauletekio av. 11, Vilnius Lithuania \\ ${ }^{2}$ Department of Geotechnics and Building Materials, Kalashnikov Izhevsk State Technical University, \\ Studencheskaya str. 7, Izhevsk, Russia
}

Received 15 July 2018; accepted 27 August 2018

\begin{abstract}
This article presents a research into the impact of plasticising admixtures on drying shrinkage of cementitious composites by evaluating the effectiveness of plasticising. Materials used in the study: Portland cement CEM I 42.5 R, plasticiser LS (modified lignosulphonates based), superplasticiser PCE (synthetic polycarboxylate esters based), superplasticiser MAP (modified acrylic polymers based), sand and water. The percentage change of plastic viscosity of cement paste indicates the effectiveness of plasticising of cementitious composites. The change of plastic viscosity has been tested by adding a specific amount of plasticising admixtures. The effectiveness of plasticising of pastes were tested using rotational viscometer. Chemical admixtures content in pastes varied from 0 to $1.2 \%$. Drying shrinkage was tested based on length change of the specimens with fine aggregates. The method to minimise drying shrinkage of composites was established through use of plasticising admixtures. It has been found that by increasing plasticising admixture dosage from 0 to $1.2 \%$ the following changes occur: LS plasticising effectiveness increases by $35 \%$ while drying shrinkage decreases by $8 \%$; MAP plasticising effectiveness increases by $70 \%$ while drying shrinkage decreases by $16 \%$; PCE plasticising effectiveness increases by $80 \%$ while drying shrinkage decreases by $20 \%$.
\end{abstract}

Keywords: cementitious composites, drying shrinkage, plastic viscosity, plasticisers, superplasticisers, the effectiveness of plasticising.

\section{Introduction}

Ever since Joseph Aspdin took out a patent for Portland Cement in 1824, users strove to make structures including it more reliable and stable (Biernacki et al., 2017). From Joseph Monier's 1849 reinforced concrete to the most modern of developments - concretes such as selfcompacting concrete, ultra-high performance concrete, and eco-friendly concretes - people wanted to get cementbased structures and surfaces to behave more predictably. One of the most common challenges remaining today is shrinkage of cementations composites. The problems caused by it are of different significance, depending on the structure or surface in question, but also of virtually universal occurrence. Since this deformation is characterised by long-term manifestation with ensuing problems, drying shrinkage is particularly problematic for concrete structures, especially reinforced (Biernacki et al., 2017).
Shrinkage has potential to cause significant delayed deformations and cracking and is thus "a major parameter when designing reinforced concrete structures" (Hooton \& Bickley, 2014). Unsurprisingly, it forms a part of performance-based specifications for durability (Hooton \& Bickley, 2014).

It is common knowledge that cement-based materials are sensitive to water. When the surrounding humidity is lower than that of a concrete structure, drying naturally occurs, potentially leading to shrinkage and/or cracking. This is also linked to rise of capillary pressure, disjoining pressure and surface energy which creates internal compressive stresses in the solid skeleton (Meschke, Pichler, \& Rots, 2018). Cracking occurs due to two mechanisms: differential drying shrinkage between the core and the surface; strain incompatibilities between cement paste

*Corresponding author. E-mail: mindaugas.macijauskas@vgtu.lt 
(subjected to drying shrinkage) and stiff aggregates (Meschke et al., 2018).

In terms of methodological assessment, cement-based material shrinkage is generally known as the strain in the absence of additional external stress. The consumption of water by cement hydration (known as "self-desiccation") and the water loss due to the mentioned moisture gradient with the external environment result in a decrease in relative humidity within the porous concrete compound. This leads to creation of menisci and internal pressures. Ulm, Constantinides, and Heukamp (2004) confirm the poromechanics aspect of the cement-based materials which consequently makes it very sensitive to the pressure that develops in the porosity of cement-based materials, albeit to varying extent, depending on the type of compound, i.e. cement paste, mortar or concrete. In the cases of autogenous shrinkage, drying shrinkage or the coupling between them, three mechanisms, as distinguished by Yates (1954) and adopted by Bentz, Garboczi, and Quenard (1998), generate the strain from the water departure. Capillary pressure, disjoining pressure which shows a relative humidity dependency similar to capillary pressure, and the specific surface free energy variation in adsorbed layer especially for a lower relative humidity (Mindess, Young, \& Darwin, 2003).

One of the best ways to deal with this issue is application of admixtures, generally developed to improve the quality and optimise the properties of concretes, like ease of placement, extent of control of workability, etc. Since the cost of building processes, especially on the industrial scale, is significant, it is immensely beneficial to increase workability and prolong the period of time when mistakes can still be rectified relatively easily. Thus, plasticising admixtures have become key ingredients of prepared modern concretes. (Macijauskas \& Girskas, 2017) Importantly, since the quality and properties of the particular concrete depend on the quality and properties of each constituent ingredient used in the mixture (Tattersall \& Banfill, 1986; O. Wallevik, Feys, J. Wallevik, and Khayat, 2015), the admixtures can also help with the shrinkage issue. The most commonly used plasticising admixtures are lignosulphonates (LS), synthetic polymers, such as modified acrylic polymers (MAP) and polycarboxylate esters (PCE) (Gelardi et al., 2016). LSs, which have a limited water reduction ability of about $10 \%$ and are mainly used to enhance the fluidity retention in ready-mix applications. By contrast, synthetic polymers (MAP and PCE) have exceptionally versatile chemical structures and can achieve water reduction of up to $40 \%$.

Water reduction, as our findings suggest, is actually one the best ways to control shrinkage. Generally, the main purpose of using plasticising admixtures is to increase the fluidity without adding excessive amounts of water. As Gelardi and Flatt (2016) explained, at the lowest, molecular, level, plasticising admixtures "physically separate the cement particles by opposing their attractive forces with steric and/or electrostatic forces". That, consequently, makes the fresh concrete mixture easier to work, place and shape. In this paper we also argue that reducing the amount of water in the original compound whilst retaining workability is a very effective method of shrinkage reduction.

Compared with naphthalene plasticisers, polycarboxylate superplasticisers have a better water-reducing effect, but also increase air content, as a side effect (Qian, Zhang, Huang, Qu, \& Guo, 2016). Their principle of operation differs: the water-reducing effect of naphthalene is mainly caused by electrostatic repulsion, but the water reduction mechanism of polycarboxylate superplasticisers is essentially generated by steric hindrance. As Qian et al. (2016) observed, these different mechanisms may show different influences on self-desiccation shrinkage and drying shrinkage. This paper thus contributes to existing knowledge by exploring these influences.

Whilst the interactions between cement and plasticising admixtures have been explored before, not enough scientific data has been found on, in particular, the effectiveness of the plasticising admixtures on shrinkage control. Through our testing process, we discovered and henceforth provide more scientific data on the impact of dosage and effectiveness of commonly used plasticising admixtures (modified lignosulphonates, modified acrylic polymers and synthetic polycarboxylate esters-based ones). This article evaluates the impact of plasticizing admixtures on drying shrinkage of cementitious composites by evaluating the effectiveness of plasticising.

\section{Materials used and compositions of tested mixtures}

Portland cement CEM I R, according to LST EN 1971:2011 (Lietuvos standartizacijos departamentas, 2011) (strength class $42.5 \mathrm{R}$ ), produced by JSC Akmenès Cementas was the main cement used for the purposes of this experimental research. Cement mineral composition (according to Bogue calculation) was $\mathrm{C}_{3} \mathrm{~S}-53.56 \%$, $\mathrm{C}_{2} \mathrm{~S}-17.23 \%, \mathrm{C}_{3} \mathrm{~A}-1.43 \%, \mathrm{C}_{4} \mathrm{AF}-10.40 \%, \mathrm{SO}_{3}-3.47 \%$, LOI $-2.10 \%$, with particle density being $3.12 \mathrm{~g} / \mathrm{cm}^{3}$ and dry bulk density $-1.24 \mathrm{~g} / \mathrm{cm}^{3}$. The average size of particle is $12.38 \mu \mathrm{m} .50 \%$ of particles are smaller than $15.50 \mu \mathrm{m}$. Physical properties of the cement used are displayed in Table 1. The particle size distribution of cement and its granulometry curve are presented in Figure 1. These pa-

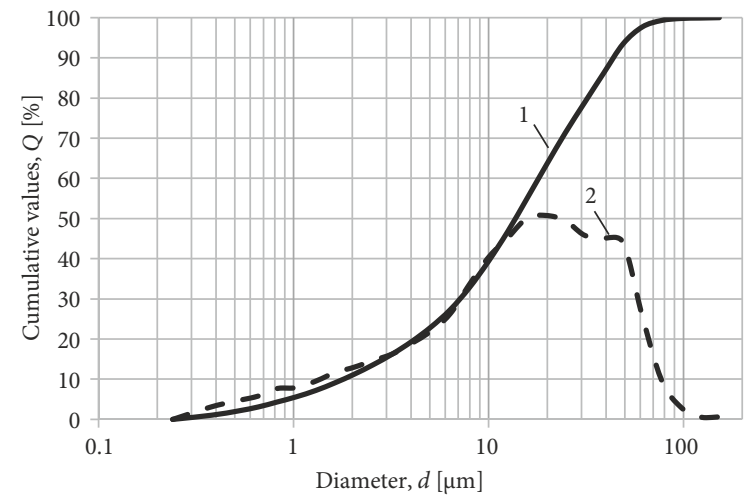

Figure 1. Cement CEM I 42.5 R particulate levels distribution by size: 1 - distribution of the relative amount of particles according to size; 2 - distribution of absolute quantity of particles by size 
Table 1. Physical properties of the cement according to LST EN 197-1:2011 (Lietuvos standartizacijos departamentas, 2011)

\begin{tabular}{|c|c|c|c|c|c|c|c|}
\hline \multirow{2}{*}{ Type of cement } & \multicolumn{2}{|c|}{ Compressive strength, MPa } & \multicolumn{2}{|c|}{ Setting time, min } & \multirow{2}{*}{ Standard consistence } \\
\cline { 2 - 5 } & 2 days & 28 days & initial & final & \multirow{2}{*}{ Fater content in $\%)$} & $\begin{array}{c}\text { Blaine, } \\
\mathrm{cm}^{2} / \mathrm{g}\end{array}$ & $>90 \mu \mathrm{m}, \%$ \\
\hline CEM I 42.5 R & 29.8 & 56.4 & 140 & 170 & 27.6 & 4198 & 1.6 \\
\hline
\end{tabular}

Table 2. Technical information on chemical admixtures

\begin{tabular}{|l|l|c|c|c|c|c|c|}
\hline $\begin{array}{c}\text { Class of } \\
\text { admixture }\end{array}$ & \multicolumn{1}{|c|}{ Type of admixture } & $\mathrm{pH}\left(20^{\circ} \mathrm{C}\right)$ & $\begin{array}{c}\text { Bulk density, } \\
\mathrm{g} / \mathrm{cm}^{3}\end{array}$ & $\begin{array}{c}\text { Max. } \\
\text { chloride } \\
\text { content, \% }\end{array}$ & $\begin{array}{c}\text { Max. alkali } \\
\text { content, \% }\end{array}$ & $\begin{array}{c}\text { Dry solids } \\
\text { content, \% }\end{array}$ & $\begin{array}{c}\text { Recommended } \\
\text { dosage, \% of } \\
\text { cement wt. }\end{array}$ \\
\hline LS & $\begin{array}{l}\text { Plasticiser based on } \\
\text { modified lignosulphonates }\end{array}$ & $8.00 \pm 1.00$ & $1.20 \pm 0.03$ & $\leq 0.05$ & $\leq 6.00$ & $39.00 \pm 2.00$ & $0.5-0.8$ \\
\hline PCE & $\begin{array}{l}\text { Superplasticiser based on } \\
\text { synthetic polycarboxylate } \\
\text { ester }\end{array}$ & $6.00 \pm 1.00$ & $1.06 \pm 0.01$ & $\leq 0.10$ & $\leq 0.10$ & $27.00 \pm 1.00$ & $0.6-1.2$ \\
\hline MAP & $\begin{array}{l}\text { Superplasticiser based on } \\
\text { modified acrylic polymers }\end{array}$ & $6.50 \pm 1.00$ & $1.06 \pm 0.02$ & $<0.05$ & $<2.50$ & $22.00 \pm 1.00$ & $0.6-1.2$ \\
\hline
\end{tabular}

rameters were determined using Cilas 1090 Liquid (produced in France).

The following plasticising admixtures were used in the investigation: plasticiser (LS), superplasticisers (PCE and MAP). Characteristics of chemical admixtures are shown in Table 2.

$0 / 4$ fraction sand (0-4 $\mathrm{mm}$ sand particles) complying with LST EN 12620:2003+A1:2008 (Lietuvos standartizacijos departamentas, 2008) was used as fine aggregate. Physical properties and the particle size distribution of sand are presented in Table 3 and Table 4. Particle size distribution of sand was determined according to LST EN 933-1:2012 (Lietuvos standartizacijos departamentas, 2012).

The assessment of the effectiveness of plasticising and required amount of water for preparing cement pastes

Table 3. Physical properties of sand

\begin{tabular}{|c|c|l|c|}
\hline Aggregate & Fraction & \multicolumn{1}{c|}{ Characteristics } & Test results \\
\hline \multirow{2}{*}{ Sand } & \multirow{2}{*}{$0 / 4$} & Particle density, $\mathrm{kg} / \mathrm{m}^{3}$ & 2645 \\
\cline { 3 - 4 } & & Bulk density, $\mathrm{kg} / \mathrm{m}^{3}$ & 1540 \\
\cline { 3 - 4 } & & Water absorption, $\%$ & 1.35 \\
\hline
\end{tabular}

Table 4. Sand particle size distribution

\begin{tabular}{|c|c|}
\hline Sieve aperture, $\mathrm{mm}$ & Passed, $\%$ \\
\hline 5.6 & 100 \\
\hline 4 & 99.20 \\
\hline 2 & 91.67 \\
\hline 1 & 75.73 \\
\hline 0.5 & 46.47 \\
\hline 0.25 & 10.13 \\
\hline 0.125 & 2.37 \\
\hline$<0.063$ & 0.6 \\
\hline
\end{tabular}

of equivalent viscosity was conducted via rheological research on plasticised cement pastes. The cement paste $(\mathrm{W} / \mathrm{C}=0.32)$ with plasticiser LS and paste $(\mathrm{W} / \mathrm{C}=0.30)$ with superplasticiser PCE or MAP were tested. Chemical admixtures content in cement pastes varied from 0 to $1.2 \%$ of the cement weight with interval-based addition every $0.2 \%$. Bigger dosages were not investigated because segregation of cement paste occurred. It is worth mentioning that different values of dry solids content of different plasticising admixtures were considered when determining admixture dosages value in cement pastes.

For the purposes of required amount of water change measurement and the impact of that change on mortar shrinkage during its curing period, we developed certain compositions provided in Table 5. Sand proportion in the mortar was recalculated to maintain the same mortar strength class, while keeping cement amount the same and reducing water demand.

The first composition (Vsk0) is the base. From the second (Vsk1) incrementally towards the seventh (Vsk6) composition the required amount of water was being reduced $5-30 \%$ respectively (5\% interval). Notably, as we

Table 5. Compositions of $1 \mathrm{~m}^{3}$ of mortar

\begin{tabular}{|l|c|c|c|c|c|c|c|}
\hline \multicolumn{1}{|c|}{ Mortar index } & Vsk0 & Vsk1 & Vsk2 & Vsk3 & Vsk4 & Vsk5 & Vsk6 \\
\hline $\begin{array}{l}\text { Reduction of } \\
\text { required amount } \\
\text { of water }(\Delta \mathrm{W}), \%\end{array}$ & 0 & 5 & 10 & 15 & 20 & 25 & 30 \\
\hline Cement, kg & 214 & 203 & 191 & 180 & 169 & 155 & 142 \\
\hline Water, l & 1705 & 1733 & 1761 & 1789 & 1816 & 1844 & 1872 \\
\hline Sand, kg & 0 & 0.2 & 0.4 & 0.6 & 1.0 & 1.6 & 2.4 \\
\hline $\begin{array}{l}\text { Superplasticiser } \\
\text { (MAP) dosage } \\
\text { (X), as percentage } \\
\text { of cement mass }\end{array}$ & 0.53 & 0.50 & 0.47 & 0.45 & 0.42 & 0.38 & 0.35 \\
\hline W/C & & & & & & & \\
\hline
\end{tabular}


reduced the amount of water, we also incrementally increased the dosage of superplasticiser (MAP), in order to maintain the consistency (slump flow) of mortar.

\section{Research methods}

\subsection{Methodology of determining the effectiveness of plasticising and required amount of water for preparing cement pastes of equivalent viscosity}

Cement paste was mixed in a planetary mixer according to LST EN 196-3:2017 (Lietuvos standartizacijos departamentas, 2017). The mixing procedure was as follows: cement and 3/4 of the required water were mixed for $2 \mathrm{~min}$ at high speed ( $140 \pm 5$ r.p.m.). Subsequently, the remaining water and plasticising admixture (LS, PCE or MAP) were added. Finally, cement paste was mixed further for $3 \mathrm{~min}$ at high speed.

The rheological properties of cement paste were tested using rotational viscometer (Rheotest RN4.1) with coaxial cylinders. The cylinder measuring system of viscometer consists of the measuring cup (assembled) (1) with coupling (3) and cylinder rotor (2). The dimensions of testing cylinders are presented in Figure 2.

The cement paste is poured into a measuring cup (1), which is fixed and stationed in the equipment stand. Inside the measuring cup the cylinder rotor (2) rotates. Because of the intrinsic friction of the layers of the cement paste (4) observed between the measuring cup (1) and the rotating cylinder rotor (2) positioned in the measuring cup and connected to a measuring scale, the cylinder rotor (2) makes a turn and the data displayed on the measuring scale changes. The shear rates regime used in the test is presented in (Macijauskas \& Girskas, 2017).

Rheological properties of the cement paste were tested $10 \mathrm{~min}$ after the start of mixing. The yield stress $\left(\tau_{0}\right)$ and plastic viscosity $\left(\mu_{\text {pl. }}\right)$ of the cement paste were calculated based on the flow curve (shear stress " $\tau$ " and shear rate " $\gamma$ " curve) obtained after the test with rotational viscometer. The flow curve of the cement paste was analysed adopting the Bingham rheological model using linear approxima-

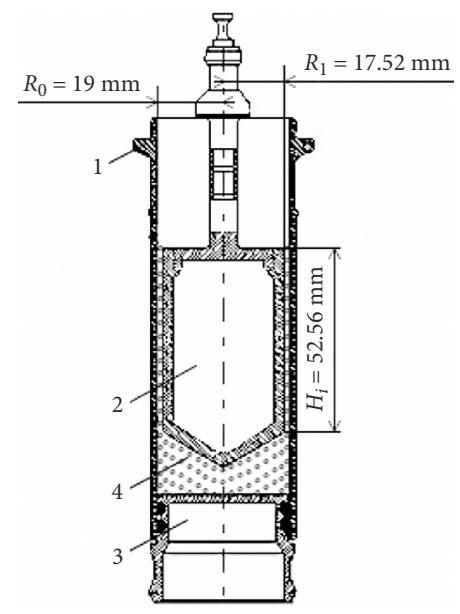

Figure 2. Principle schema of the testing cylinders tion of experimental results up to $40 \mathrm{~s}^{-1}$ shear rate when the flow curve of cement paste is linear.

The effectiveness of plasticising is determined by increasing a dosage of plasticising admixture at a constant $\mathrm{W} / \mathrm{C}$ ratio of the cement paste. The percentage change of plastic viscosity, based on the given equation (1), measures the effectiveness of plasticising admixtures.

$$
E f f_{\mathrm{pl}}=\frac{\mu_{\mathrm{pl} .0}-\mu_{\mathrm{pl} . i}}{\mu_{\mathrm{pl} .0}} \cdot 100, \%,
$$

where: $\mu_{\text {pl.o }}$ - plastic viscosity of the cement paste without plasticising admixture, Pa.s; $\mu_{\mathrm{pl} . i}$ - plastic viscosity of the plasticised cement paste, Pa.s.

Notably, when different plasticising admixtures (of different chemical composition) are used in different dosages (from 0 to $1.2 \%$ of cement paste), required amount of water change for preparing Portland cement pastes of equal viscosity is determined experimentally.

\subsection{Specimens with fine aggregates drying shrinkage measuring method}

The mortars were prepared using Automix laboratory type force-mix mixer over the course of six minutes, in three stages. At stage one the mixer surfaces were covered with minimal amounts of water. Subsequently, cement and dried sand were introduced and mixed for one minute at first (lowest) speed (140 \pm 5 r.p.m.) of the mixer. During the second stage $3 / 4$ of the required amount of water was added with continued mixing for 2 minutes at first speed. The third stage involved introduction of the remaining amount of water with or without a plasticising admixture with continued mixing for 3 minutes at second speed (285 \pm 10 r.p.m.).

Technical mortar properties were determined according to Lithuanian official standards: slump flow - LST EN 1015-3:2002 (Lietuvos standartizacijos departamentas, 2002a), mortar bulk density - LST EN 1015-6:2002 (Lietuvos standartizacijos departamentas, 2002b).

Once the mortar technological properties were determined, mortar prisms were formed $(40 \times 40 \times 160 \mathrm{~mm})$, in order to observe drying shrinkage deformations. Specimens were compacted by using vibration, employing vibrating table for $30 \pm 5 \mathrm{~s}$.

All specimens were cast and cured for 24 hours in plastic lid covered metal forms in $20 \pm 2{ }^{\circ} \mathrm{C}$ temperature environment. After they were removed from the forms, all specimens were stored and cured in $20 \pm 2{ }^{\circ} \mathrm{C}$ temperature and $40 \pm 5 \%$ humidity environment. Notably, the specimens were additionally cured in plastic lid for 6 days at $20 \pm 2{ }^{\circ} \mathrm{C}$.

Mortar drying shrinkage deformations were periodically measured from day 2 until a 6 month deadline. The length comparator with $0.001 \mathrm{~mm}$ standard deviation of dial gauge was used for this measurement. For every mortar composition, three specimens were formed. Mortar drying shrinkage deformation margin was determined after calculating the average margin of all three specimens. 
Given different curing duration, the mortar drying shrinkage is calculated using the following formula (2).

$$
S h_{x}=\frac{l_{0}-l_{x}}{l_{0}} \cdot 10^{3} \text {. }
$$

In this formula: $S h_{x}-$ mortar shrinkage after a particular day of curing, $\mathrm{mm} / \mathrm{m} ; l_{0}$ - initial length of the specimen after 1 st day of curing, $\mathrm{mm}$; $l_{x}$ - length of the specimen after a particular day of curing, $\mathrm{mm}$.

\section{Experiment results}

\subsection{The influence of plasticising admixtures on rheology of Portland cement pastes}

The influence of the plasticiser based on modified lignosulphonates (LS) and the superplasticiser based on polycarboxylate esters (PCE) and modified acrylic polymers (MAP) on the flow behaviour of modified Portland cement pastes was investigated.

It is evident, from the obtained flow curves (Figure 3), that the flowability of the Portland cement pastes depends on the chemical composition and dosage of the plasticising admixtures 10 minutes after the beginning of mixing.

Figure 3 shows that the superplasticiser (PCE) increases the paste flowability better than the plasticiser (LS) and a different superplasticiser (MAP). Increasing the dosage of the plasticising admixtures from 0 to $0.8 \%$ of the cement weight and with the increase of the shear rate from 10 to $40 \mathrm{~s}^{-1}$, the flowability of the Portland cement paste increases: the shear stress decreases from 142.8 to $98.7 \mathrm{~Pa}$, when the paste is modified with the plasticiser (LS); from 193.4 to $49.96 \mathrm{~Pa}$, when the paste is modified with the superplasticiser (PCE); from 193.4 to $71.36 \mathrm{~Pa}$, when the paste is modified with the superplasticiser (MAP). Meanwhile, when increasing the dosage of the plasticising admixtures from 0.8 to $1.2 \%$, the paste flowability increases marginally.

Applying the Bingham rheological model for the obtained flow curves of the modified Portland cement pastes (Figure 3), an exponential relationship was found between the different dosage of the plasticising admixtures and the paste yield stress $\tau_{0}$ (Figure $4 \mathrm{a}$ ) as well as the plastic viscosity $\mu_{\mathrm{pl}}$. (Figure $4 \mathrm{~b}$ ), 10 minutes after the beginning of paste mixing.

Increasing the dosage of the plasticising admixtures (LS, PCE or MAP) from 0 to $0.8 \%$ of cement weight, not only the flowability of modified Portland cement pastes increases (Figure 3), but also their rheological properties change (Figure 4). Meanwhile, when increasing the dosage of plasticising admixtures from 0.8 to $1.2 \%$, the rheological properties of the pastes do not change significantly.

It was found that the superplasticiser (PCE) reduces the yield stress and plastic viscosity of modified Portland cement paste more effectively than the plasticiser (LS) and the superplasticiser (MAP). Figure 4a shows that when the dosage of the plasticising admixtures is increased from 0 to $0.8 \%$ of cement weight, the yield stress decreases: from

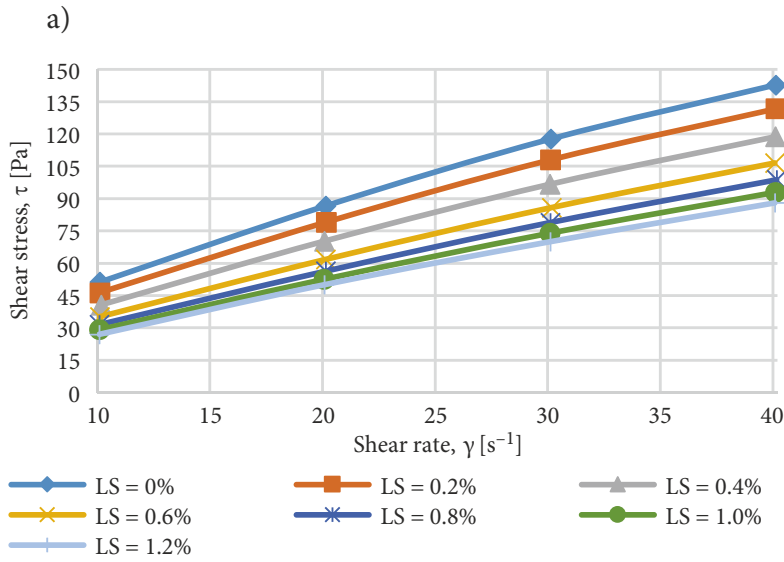

b)

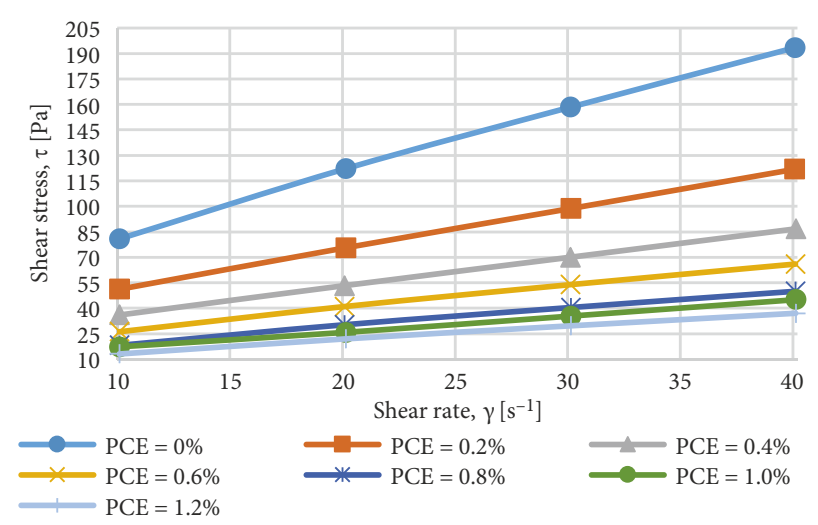

c)

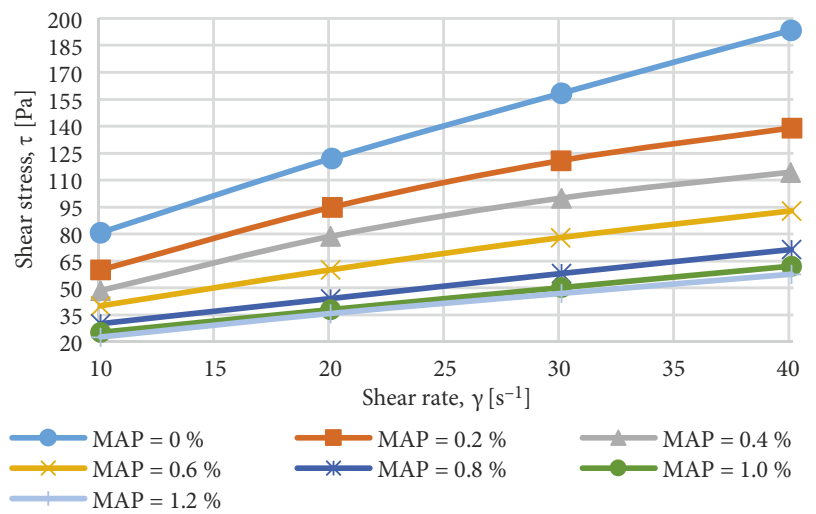

Figure 3. Dependence of the shear stress of the modified Portland cement pastes on the shear rate 10 minutes after the beginning of the paste mixing: a) with the plasticiser (LS); b) with the superplasticiser (PCE); c) with the superplasticiser (MAP)

22.77 to $10.1 \mathrm{~Pa}$, when the paste is modified with the plasticiser (LS); from 44.69 to $8.15 \mathrm{~Pa}$, when the paste is modified with a superplasticiser (PCE); from 44.69 to $16.3 \mathrm{~Pa}$, when the paste is modified with a different superplasticiser (MAP). At the same time, Figure $4 \mathrm{~b}$ shows that the plasticiser (LS) reduces the plastic viscosity of the modified paste from 3.06 to $2.24 \mathrm{~Pa} \cdot \mathrm{s}$, superplasticiser (PCE) from 3.72 to $1.06 \mathrm{~Pa} \cdot \mathrm{s}$, and superplasticiser (MAP) - from 3.72 to $1.38 \mathrm{~Pa} \cdot \mathrm{s}$. 

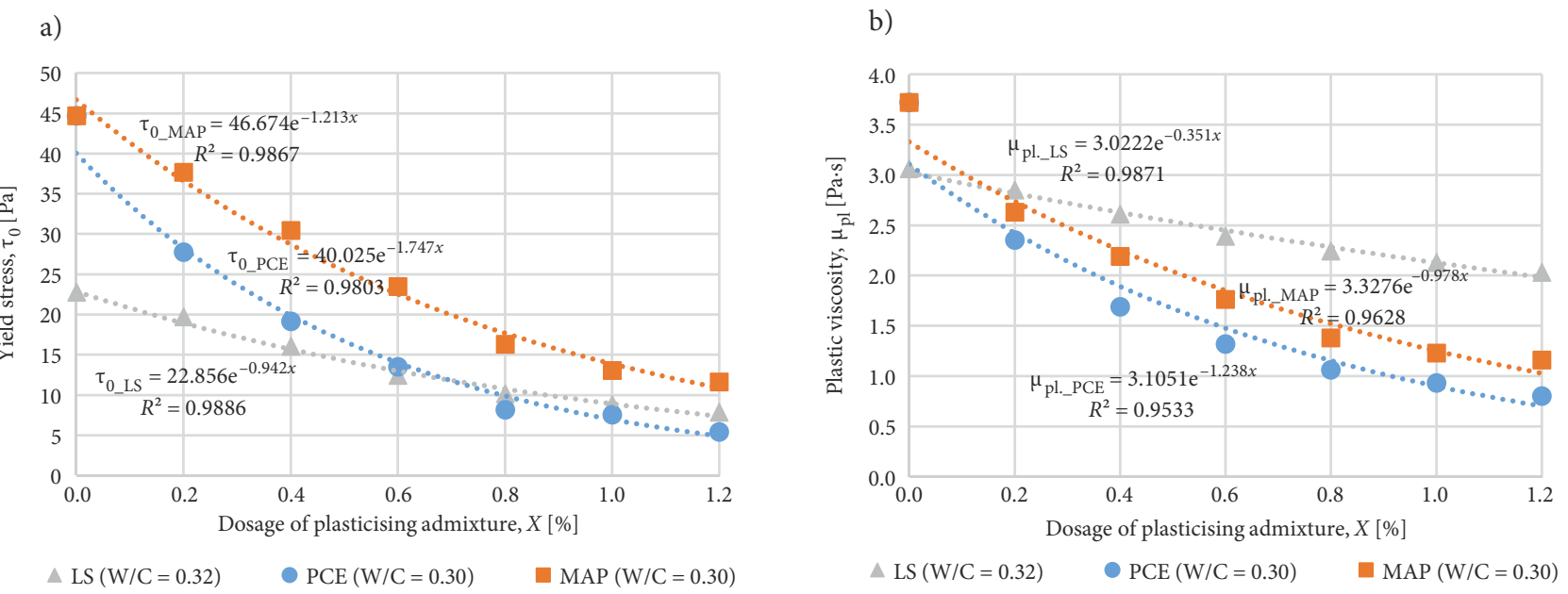

Figure 4. Dependence of the shear stress of modified Portland cement pastes (a) and the plastic viscosity (b) on different dosage of plasticising admixtures 10 minutes after the beginning of paste mixing

The principle of dispersing of the plasticiser based on modified lignosulphonates (LS) is based on the electrostatic dispersion of cement particles in the paste. The dispersion of the superplasticisers is based on synthetic polycarboxylate ester and modified acrylic polymers (PCE and MAP) - with an additional spatial rejection effect. From the results obtained (Figure 3 and 4), it can be stated that the size of the dispersion effect of cement particles in the Portland cement paste depends on the chemical composition and dosage of the plasticising admixtures. As the dispersion effect of the cement particles increases, the distance between the cement particles increases and the size of traction forces and the number of connections between them decreases, the effect of which results in decrease of the yield stress and plastic viscosity.

\subsection{The effectiveness of plasticising and its impact on the water demand for obtaining the Portland cement paste of equivalent viscosity}

The influence of the plasticiser (LS) and the superplasticisers (PCE and MAP) on the effectiveness of plasticising of the Portland cement pastes 10 minutes after the beginning of the paste mixing was determined in this research (Figure 5).

Figure 5 shows that the effectiveness of plasticising depends on the chemical composition and dosage of the plasticising admixtures. It has been determined that the plasticiser based on modified lignosulphonates (LS) evenly increases the effectiveness of plasticising from 8 to $35 \%$, increasing the dosage of the admixture from 0.2 to $1.2 \%$ of the cement weight. The superplasticiser based on synthetic polycarboxylate ester (PCE) and the superplasticiser based on modified acrylic polymers (MAP) intensively and significantly increases the effectiveness of plasticising from 38 to 72 and from 30 to $63 \%$, respectively, when the dosage of the respective superplasticiser is increased from 0.2 to $0.8 \%$ of the cement weight. A further increase in the dosage of the superplasticiser (PCE and MAP) up to $1.2 \%$ increases the effectiveness of plasticising to a significantly lesser extent.

In the case of different plasticising admixtures (different chemical composition) and their dosages (from 0.2 to $1.2 \%$ of the cement weight), experimentally the change in water demand was determined for obtaining the modified Portland cement pastes of the equivalent viscosity (Figure 5).

Figure 5 shows that increasing the dosage of the plasticiser (LS) from 0.2 to $1.2 \%$ of the cement weight, the reduction in the water demand of the modified Portland cement paste is steadily increasing from 3 to $11 \%$, while increasing the dosage of the superplasticiser (PCE and MAP) from 0.2 to $0.8 \%$, the reduction in the paste water demand intensively increases from 15 to $30 \%$ and from 12 to $25 \%$, respectively. Further increase of the dosage of the superplasticiser (PCE and MAP) up to $1.2 \%$ increases the reduction in the paste water demand to 32 and $28 \%$, respectively.

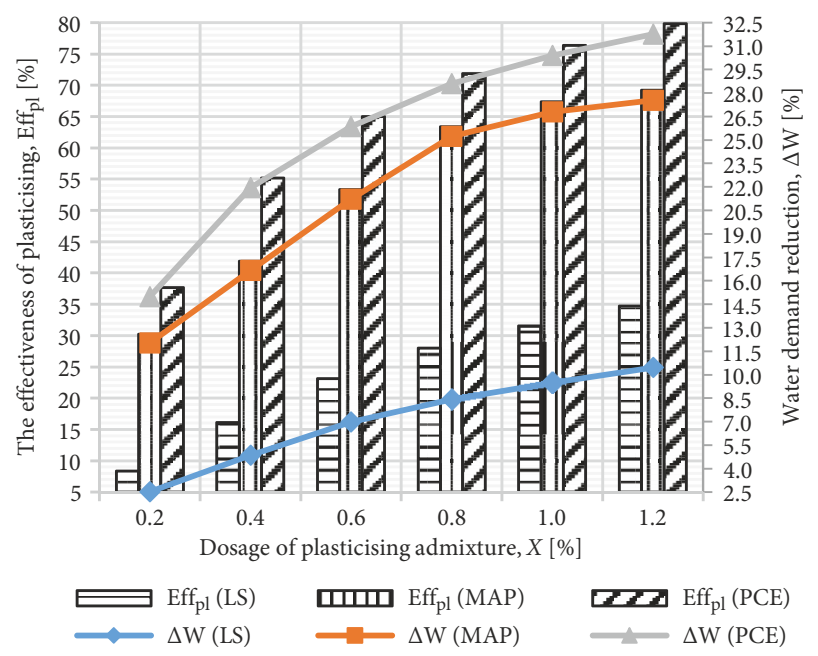

Figure 5. The effectiveness of plasticising of the plasticiser (LS) and the superplasticiser (MAP and PCE) and its influence on demand for the paste water, maintaining their equivalent viscosity 
Summarizing the results obtained (Figure 5), it can be argued that the superplasticiser based on synthetic polycarboxylate ester (PCE) has a greater effectiveness in plasticising and reduction of water demand of the modified Portland cement paste, than the plasticiser based on modified lignosulphonates (LS) and the superplasticiser based on modified acrylic polymers (MAP). The recommended dosage of the superplasticiser (PCE) is $0.8 \%$ of the cement weight.

After investigating the influence of the effectiveness of plasticising of the plasticising admixtures on the change in the water demand, a linear relationship was found between the reduction in the water demand and the increase of plastic viscosity of the Portland cement paste (Figure 6).

The plastic viscosity of Portland cement pastes plasticised with the superplasticiser (PCE) was investigated in order to evaluate the influence of the effectiveness of plasticising of plasticising admixtures on the change in the water demand in different water content (the ratio of W/C) (Figure 7). The water content of the Portland ce-

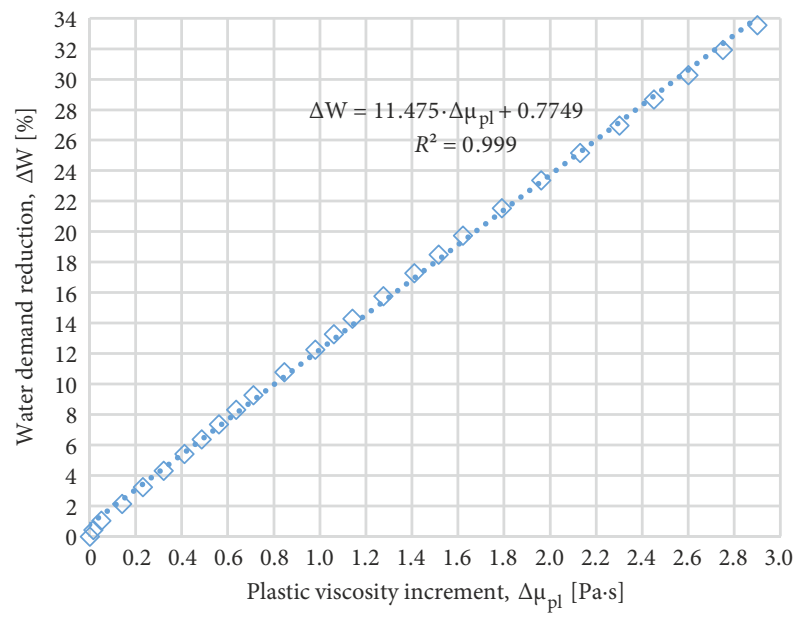

Figure 6. Dependence of reduction in the water demand on the increase of the plastic viscosity of the Portland cement paste

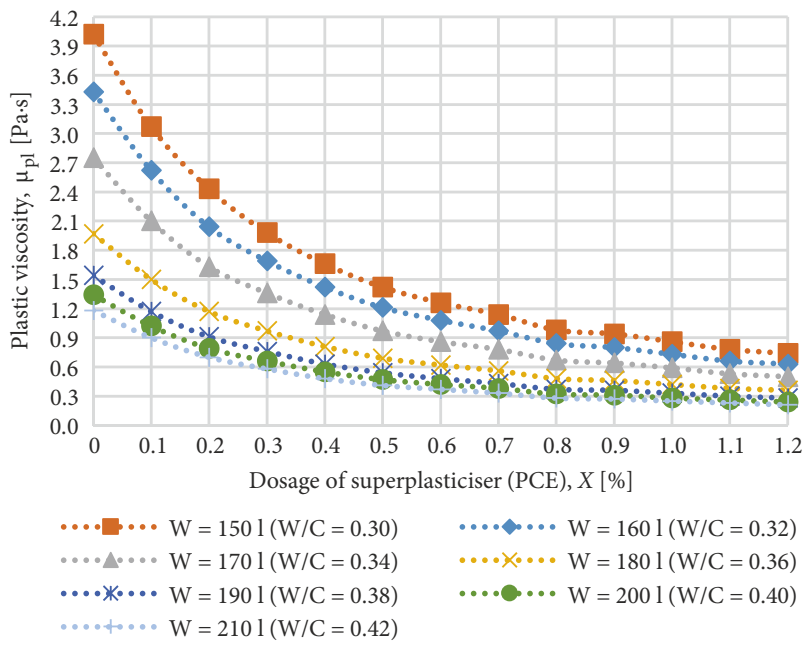

Figure 7. Dependence of the plastic viscosity of the plasticised pastes on the dosage of plasticising admixtures (PCE) in different water content (the ratio of $\mathrm{W} / \mathrm{C}$ ) ment pastes varied from $150 \mathrm{l} / \mathrm{m}^{3}$ to $210 \mathrm{l} / \mathrm{m}^{3}$, and the ratio of $\mathrm{W} / \mathrm{C}$ - from 0.30 to 0.42 respectively (interval step size -0.2 ).

The influence of the effectiveness of plasticising of plasticising admixtures on the change in the water demand in different water content is determined by interpolating the values of the values of the change in the plastic viscosity of the plasticised pastes (Figure 7) according to the obtained linear relationship between the water demand and the plastic viscosity of the paste (Figure 6). After determining the effectiveness of plasticising of the plasticising admixtures $\left(\mathrm{Eff}_{\mathrm{pl}}\right)$ and its influence on the change in the water demand in different water content, an illustrating diagram was created (Figure 8).

It was determined that reduction in the water demand for obtaining the mixtures of equivalent viscosity depends on the amount of water in the mixture. In the case of small content of water $\left(150 \mathrm{l} / \mathrm{m}^{3}\right)$, the reduction in the water demand, when the effectiveness of plasticising is $80 \%$, reaches $32 \%$. In case of the water content in the mixture of $210 \mathrm{l} / \mathrm{m}^{3}$, the reduction in the water demand reaches $6 \%$ (Figure 8).

\subsection{The influence of the change in the water demand on drying shrinkage of cement mortars}

The dependence of drying shrinkage of the cement mortars on the change in the water demand for the preparation of the mortar of equivalent slump flow at different duration of the mortar curing (Figure 9) was determined. The investigated technological properties of cement mortars with different water demand are presented in Table 6.

Table 6 shows that by decreasing water demand up to $15 \%$ and maintaining the constant consistency of the mortar (slump flow), the density of the mortar slightly increases up to $10 \mathrm{~kg} / \mathrm{m}^{3}$. Gradual reduction of water demand by up to $30 \%$, increases density of the mortar up to $2275 \mathrm{~kg} / \mathrm{m}^{3}$. Compared to the control Vsk0 mortar density $\left(2230 \mathrm{~kg} / \mathrm{m}^{3}\right)$, the density of Vsk4 increased by $24 \mathrm{~kg} / \mathrm{m}^{3}, \mathrm{Vsk} 5$ increased by $36 \mathrm{~kg} / \mathrm{m}^{3}$, and Vsk 6 - by $45 \mathrm{~kg} / \mathrm{m}^{3}$. It is important to note that the demand for the superplasticiser for Vsk4, Vsk5 and Vsk6 mortars was significantly increasing in order to maintain their equivalent slump flow. This could have been influenced by an increase in the amount of the fine aggregates (sand) in the mortar, having reduced the water demand of the mortar (Table 5).

Figure 9 shows that decreasing the water demand from 0 to $20 \%$, the drying shrinkage of the mortars steadily decreases from 1.75 to $1.50 \mathrm{~mm} / \mathrm{m}$ and from 3.03 to $2.61 \mathrm{~mm} / \mathrm{m}$, after 28 and 180 days of curing, respectively. A slight decrease in the drying shrinkage of the mortars is observed after further reduction in the water demand: after 28 days - up to $1.44 \mathrm{~mm} / \mathrm{m}$, after 180 days - up to $2.49 \mathrm{~mm} / \mathrm{m}$. This means that the drying shrinkage depends not only on the water demand in the mixture, but also on the characteristics of the microstructure of the cement stone and the capillary pores. 


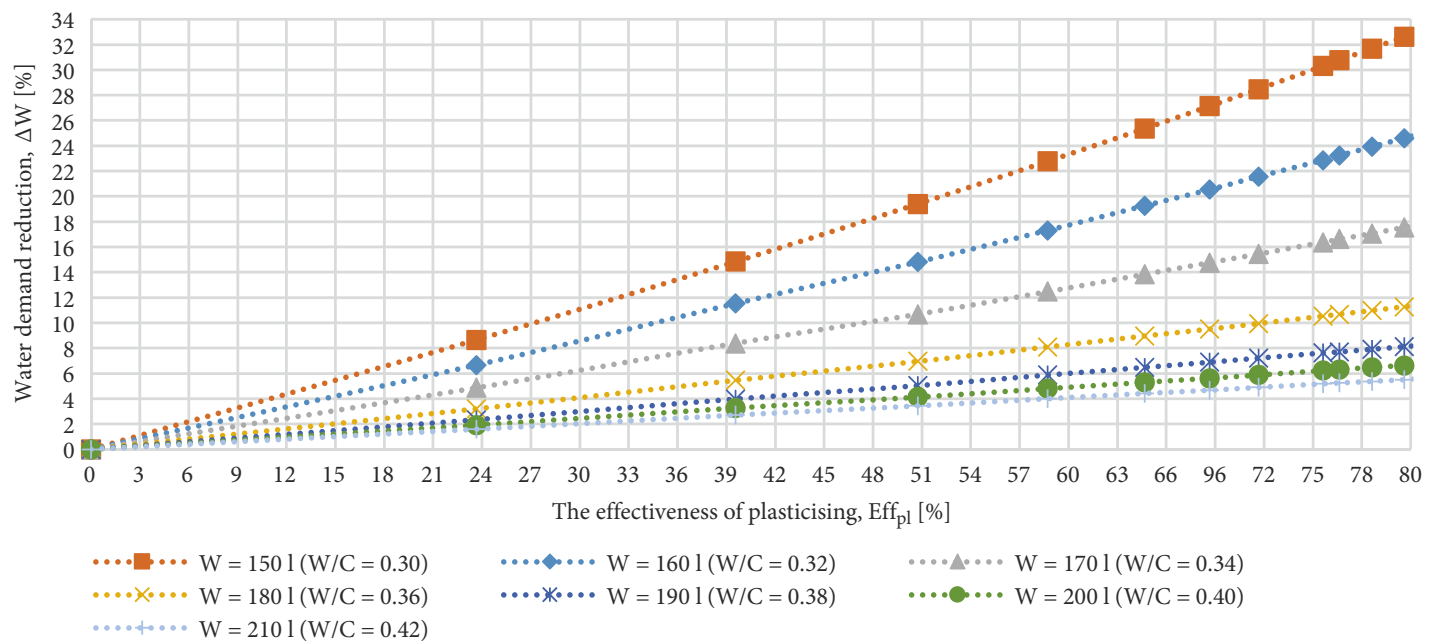

Figure 8. Diagram for the determination of water demand for mixtures of equivalent viscosity in different water content (the ratio of $\mathrm{W} / \mathrm{C}$ )
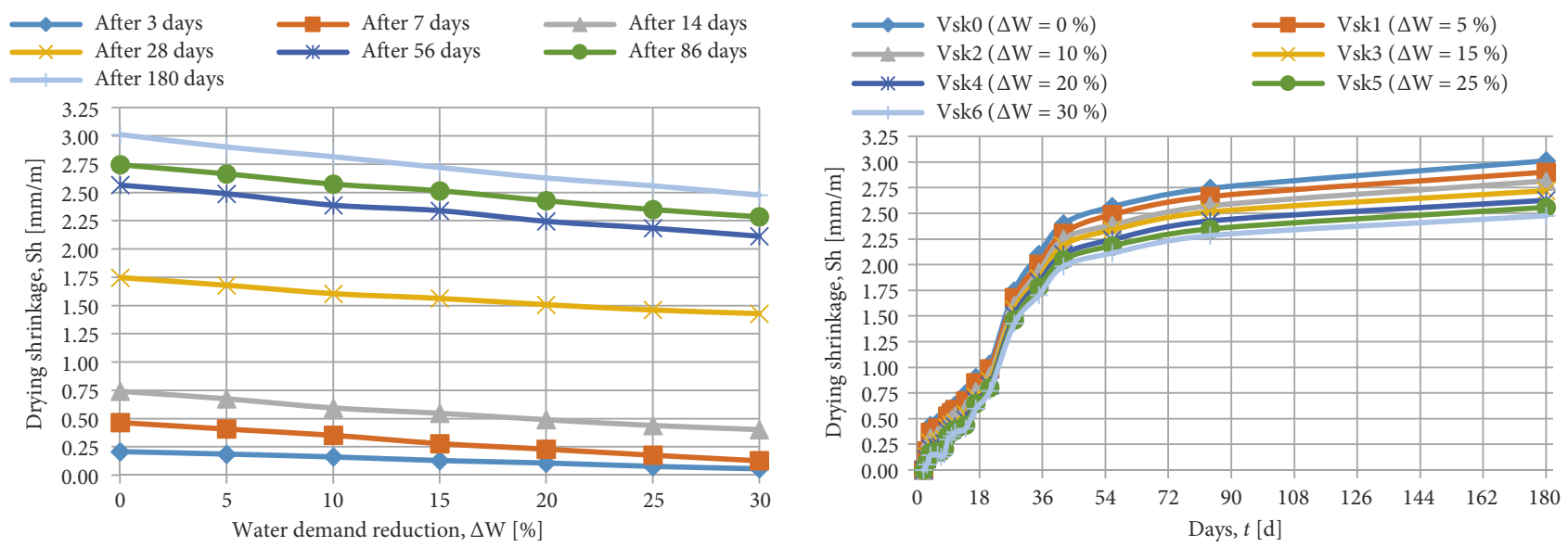

Figure 9. Dependence of the drying shrinkage of the cement mortars: a) on the reduction in the water demand; b) on the duration of curing

Table 6. The technological properties of cement mortars with different water demand

\begin{tabular}{|l|c|c|c|c|c|c|c|}
\hline \multicolumn{1}{|c|}{ Mortar marker } & Vsk0 & Vsk1 & Vsk2 & Vsk3 & Vsk4 & Vsk5 & Vsk6 \\
\hline Water demand reduction, $\Delta \mathrm{W}[\%]$ & 0 & 5 & 10 & 15 & 20 & 25 & 30 \\
\hline W/C & 0.53 & 0.50 & 0.47 & 0.45 & 0.42 & 0.38 & 0.35 \\
\hline Mortar bulk density, qmixt. $\left[\mathrm{kg} / \mathrm{m}^{3}\right]$ & 2230 & 2233 & 2236 & 2240 & 2254 & 2266 & 2275 \\
\hline Slump flow, SF $[\mathrm{mm}]$ & 120 & 120 & 120 & 120 & 115 & 115 & 115 \\
\hline
\end{tabular}

\subsection{Prediction of the drying shrinkage of the cement mortars according to the effectiveness of plasticising of plasticising admixtures}

Having determined the dependence of the drying shrinkage of the mortars on the change in the water demand (Figure 9) and the dependence of the change in the water demand on the effectiveness of plasticising of the plasticising admixtures (Figure 8), the drying shrinkage of the mortars can be predicted after 28 and 180 days of curing. The forecasting results are presented in diagrams (Figure 10).
It was found that with the increase of the effectiveness of plasticising, the water demand for preparation of mixtures of the same viscosity decreases (Figure 8), the effect of which decreases the drying shrinkage of the mortars (Figure 10). Drying shrinkage of the mortars reaches 20\% when the content of water is small $\left(150 \mathrm{l} / \mathrm{m}^{3}\right)$ and the effectiveness of plasticising is $80 \%$. Alternatively, when the content of water in the mixture is $210 \mathrm{l} / \mathrm{m}^{3}$, the reduction in the drying shrinkage of the mortars reaches $4 \%$, while the effectiveness of plasticising is unchanged at $80 \%$ (Figure 10b). 

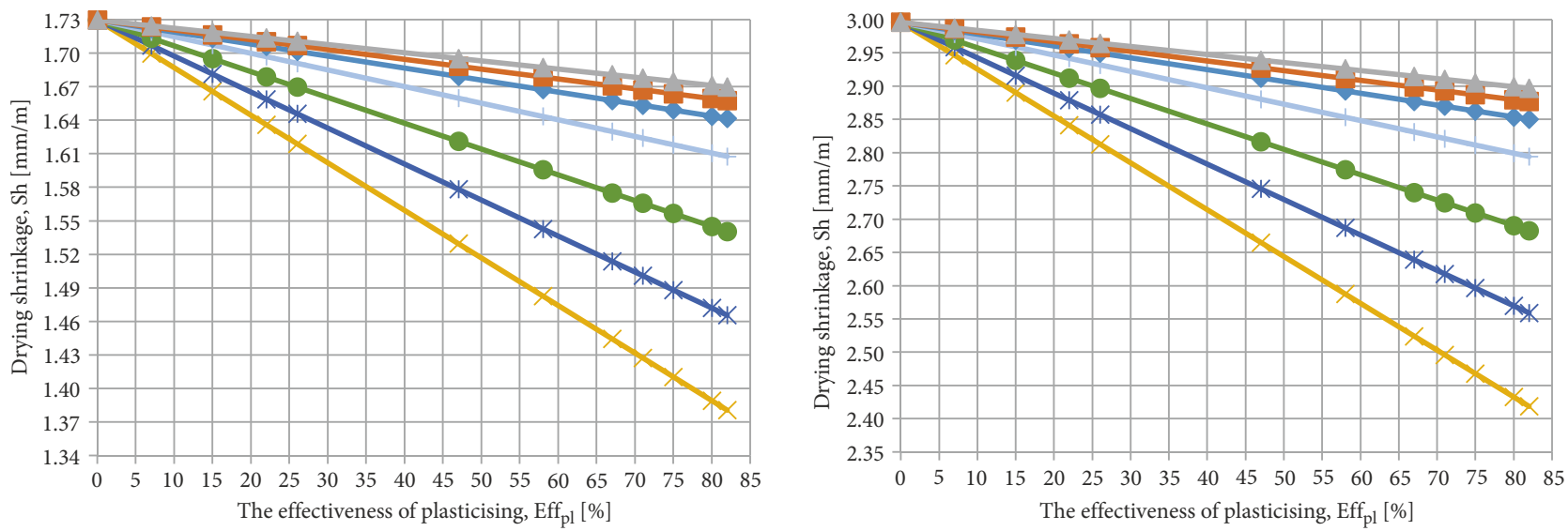

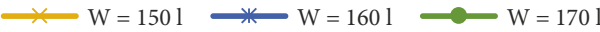
$\mathrm{W}=180 \mathrm{l}$

$\longrightarrow \mathrm{W}=190 \mathrm{~W}-\mathrm{W}=200 \mathrm{l} \longrightarrow \mathrm{W}=210 \mathrm{l}$

Figure 10. Diagram for determining the drying shrinkage of the mortar: a) after 28 days of curing; b) after 180 days of curing

\section{Conclusions}

This work has described research into 3 different plasticising admixtures and their dosage impact on drying shrinkage of cementitious composites by evaluating the effectiveness of plasticising. The research resulted in the following findings:

1. The effectiveness of plasticising of cementitious mixtures, which is an important technological indicator in the processes of concreting and transporting, must be evaluated as a percentage change in viscosity by adding a certain dosage of plasticising admixtures.

2. The effectiveness of plasticising depends on the chemical composition and dosage of the plasticising admixtures. The plasticiser based on modified lignosulphonates evenly increases the effectiveness of plasticising to $35 \%$, at the dosage of the admixtures of $1.2 \%$ of the cement weight. The superplasticiser based on synthetic polycarboxylate ester and the superplasticiser based on modified acrylic polymers intensively increase the effectiveness of plasticising to $72 \%$ and to $63 \%$, respectively, at the dosage of the admixtures of $0.8 \%$ of the cement weight. A further increase in the dosage of the plasticising admixtures up to $1.2 \%$ increases the effectiveness of plasticising only slightly.

3. The drying shrinkage of the cementitious mixtures is determined by the content of the water in the mixture. Decreasing of the water demand in the mixtures to $30 \%$, the shrinkage deformations decrease by about 0.5 $\mathrm{mm} / \mathrm{m}$ or $18 \%$.

4. The drying shrinkage of the cementitious mixtures depends on the effectiveness of plasticising of the plasticising admixtures. As the effectiveness of plasticising of the plasticiser based on modified lignosulphonates increases by up to $35 \%$, and of the superplasticiser based on synthetic polycarboxylate ester and the superplasticiser based on modified acrylic polymers up to $80 \%$ and up to $70 \%$, the drying shrinkage of the cementitious mixtures (at the water content of $150 \mathrm{l} / \mathrm{m}^{3}$ ) decreases after 180 days by about 8,20 and $16 \%$, respectively.

\section{Author contributions}

Gintautas Skripkiūnas and Mindaugas Macijauskas conceived the study and were responsible for the design and development of the data analysis. Gintautas Skripkiūnas and Mindaugas Macijauskas were responsible for data collection, analysis and interpretation. Mindaugas Macijauskas, Grigory Yakovlev and Anastasiia Ignatyeva prepared a literature review on the problem under study.

\section{Disclosure statement}

Authors declare that they do not have any competing financial, professional, or personal interests in or stemming from other interested parties.

\section{References}

Bentz, D. P., Garboczi, E. J., \& Quenard, D. A. (1998). Modelling drying shrinkage in reconstructed porous materials: Application to porous Vycor glass. Modelling and Simulation in Materials Science and Engineering, 6(3), 211-236.

https://doi.org/10.1088/0965-0393/6/3/002

Biernacki, J. J., Bullard, J. W., Sant, G., Brown, K., Glasser, F. P., Jones, S., Ley, T., Livingston, R., Nicoleau, L., Olek, J., Sanchez, F., Shahsavari, R., Stutzman, P. E., Sobolev, K., \& Prater, T. (2017). Cements in the $21^{\text {st }}$ century: Challenges, perspectives, and opportunities. Journal of the American Ceramic Society, 100(7), 2746-2773. https://doi.org/10.1111/jace.14948

Gelardi, G., \& Flatt, R. J. (2016). Working mechanisms of water reducers and superplasticizers. In P.-C. Aïtcin \& R. J. Flatt (Eds.), Science and Technology of Concrete Admixtures (Chapter 11, pp. 257-278). Elsevier.

https://doi.org/10.1016/B978-0-08-100693-1.00011-4

Gelardi, G., Mantellato, S., Marchon, D., Palacios, M., Eberhardt, A. B., \& Flatt, R. J. (2016). Chemistry of chemical admixtures. In P.-C. Aïtcin \& R. J. Flatt (Eds.), Science and technology of concrete admixtures (Chapter 9, pp. 149-218). Elsevier. https://doi.org/10.1016/B978-0-08-100693-1.00009-6

Hooton, R. D., \& Bickley, J. A. (2014). Design for durability: The key to improving concrete sustainability. Construction and Building Materials, 67, part C, 422-430.

https://doi.org/10.1016/j.conbuildmat.2013.12.016 
Lietuvos standartizacijos departamentas. (2002a). Mūro skiedinio bandymo metodai. 3 dalis. Šviežio skiedinio konsistencijos nustatymas (sklidumo metodu) (LST EN 1015-3:2002). Retrieved from https://eshop.lsd.lt/public\#/product/info/0a64032460b6-1fee-8160-b6551edb2443

Lietuvos standartizacijos departamentas. (2002b). Mūro skiedinio bandymo metodai. 6 dalis. Šviežio skiedinio tūrinio tankio nustatymas (LST EN 1015-6:2002). Retrieved from https:// eshop.lsd.lt/public\#/product/info/0a640324-60b6-1fee-8160b6551edc244a

Lietuvos standartizacijos departamentas. (2008). Betono užpildai (LST EN 12620:2003+A1:2008). Retrieved from https:// eshop.lsd.lt/public\#/product/info/0a640324-60b6-1fee8160-b6588cfc7f7a

Lietuvos standartizacijos departamentas. (2011). Cementas. 1 dalis. Iprastiniu cementu sudetis, techniniai reikalavimai ir atitikties kriterijai (LST EN 197-1:2011). Retrieved from https:// eshop.lsd.lt/public\#/product/info/0a640324-60b6-1fee-8160b65838e6784b

Lietuvos standartizacijos departamentas. (2012). Bandymai užpildu geometrinèms savybèms nustatyti. 1 dalis. Granuliometrinés sudeties nustatymas. Sijojimo metodas (LST EN 933-1:2012). Retrieved from https://eshop.lsd.lt/public\#/ product/info/0a640324-60b6-1fee-8160-b6594b761058

Lietuvos standartizacijos departamentas. (2017). Cemento bandymu metodai. 3 dalis. Rišimosi trukmių ir tūrio pastovumo nustatymas (LST EN 196-3:2017). Retrieved from https:// eshop.lsd.lt/public\#/product/info/0a640324-60b6-1fee-8160b65abff53356

Macijauskas, M., \& Girskas, G. (2017). The influence of commonly used plasticizing admixtures on the plasticizing effect of cement paste. Construction Science, 20(1), 26-32. https://doi.org/10.2478/cons-2017-0004

Meschke, G., Pichler, B., \& Rots, J. G. (2018). Computational modelling of concrete structures: Proceedings of the Conference on Computational Modelling of Concrete and Concrete Structures (EURO-C 2018), 26 February - 1 March 2018, Bad Hofgastein, Austria. CRC Press. 1034 p.

Mindess, S., Young, J. F., \& Darwin, D. (2003). Concrete ( ${ }^{\text {nd }}$ ed.). New Jersey: Prentice Hall. 644 p.

Qian, C., Zhang, Y., Huang, H., Qu, J., \& Guo, J. (2016). Influences of superplasticizers on the basic and drying creep of concrete. Structural Concrete, 17(5), 729-735.

https://doi.org/10.1002/suco.201500185

Tattersall, G. H., \& Banfill, P. F. G. (1986). Rheology of fresh concrete. Cement and Concrete Research, 16(1), p. 125. https://doi.org/10.1016/0008-8846(86)90081-5

Ulm, F. J., Constantinides, G., \& Heukamp, F. H. (2004). Is concrete a poromechanics materials? - A multiscale investigation of poroelastic properties. Materials and Structures, 37(1), 4358. https://doi.org/10.1007/BF02481626

Wallevik, O. H., Feys, D., Wallevik, J. E., \& Khayat, K. H. (2015). Avoiding inaccurate interpretations of rheological measurements for cement-based materials. Cement and Concrete Research, 78, Part A, 100-109.

https://doi.org/10.1016/j.cemconres.2015.05.003

Yates, D. J. C. (1954). The expansion of porous glass on the adsorption of non-polar gases. Proceedings of the Royal Society A Mathematical, Physical and Engineering Sciences, 224(1159), 526-544. 